\title{
Testing the Model of Relationship and Impact of Administrative Leadership on Human Resource Training and Customer Satisfaction: Structural Equation Modeling (SEM)
}

\author{
Ali Ramadan Musbah ${ }^{1}$, Nasser Habtoor ${ }^{1,2} \&$ Mohd Maram $^{2}$ \\ ${ }^{1}$ Faculty of Leadership and Management, University Science Islamic (USIM), Malaysia \\ ${ }^{2}$ Aden University, Yemen \\ Correspondence: Ali Ramadan Musbah, Faculty of leadership and Management, University Science Islamic \\ (USIM), Malaysia. E-mail: alirm1975@yahoo.com
}

Received: September 28, 2015

Accepted: January 12, 2016

Online Published: January 23, 2016

doi:10.5539/ijbm.v11n2p127

URL: http://dx.doi.org/10.5539/ijbm.v11n2p127

\begin{abstract}
The current study aimed to test and validate a proposed model of the impact of the administrative leadership on customer satisfaction. This model included an external factor which is the administrative leadership, and an internal factor which is the customer satisfaction. The study also aimed to determine the role of human resource training as a mediating factor between the administrative leadership and customer satisfaction. For achieving these research objectives, the study used a quantitative approach to analyzing the data through the use of the structural equation modeling (SEM-AMOS) to test the validity of the proposed research model. The study achieved several results, the most important of which was that the administrative leadership had a positive impact on customer satisfaction. The study also provided evidence of the positive impact of the administrative leadership on customer satisfaction through its positive impact on the training of human resources, which was used as a mediating factor.
\end{abstract}

Keywords: administrative leadership, customer satisfaction, human resources development

\section{Introduction}

In terms of successful management is the one that has a sincere desire of work to reach and maintain the success, change the prevailing traditional organizational culture and its development under the surrounding progress. Such development comes only when the organization has an administrative leadership acquainted with the surrounding matters and having the qualification and performance, this is due to the consumer culture and consciousness that had in the past and dependence on quality as the main criterion for selection and preference (Aiyad, 2013). Accordingly, when the administrative leadership became higher within the organization the probability of success became grater to reach its objectives whether organizational or personal (Al-Khudr, 2005); the administrative leadership comes to influence on the others on the basis of its strength sources, which owned by placing in the organizational structure (Hraim, 2003).

Whereas the banking system is considered as one of the pillars underpinning the economic system of the State, so its development is considered as an important developmentally requirement; given the actual intense competition and the marketing of banking services; which leaded many Libyan banks to pursue and adopt the idea and the concept of quality management, but in most of these banks are still suffering from distortions, failure and weakness in the used technology efficient as banking systems limited efficiency, as well as the lack of a communications network linking banks and branches which affects the efficiency of banking operations performance, in addition to continuously deficiencies in the training of human resources (Ben Gadara, 2013) which contribute in the development of the personnel capacities, skills and attitudes (Ben Ishi, 2012); furthermore there is a weakness in the material and moral incentives, which leads to the inability to attract and maintain efficient elements, as well as the lack of customer satisfaction with the quality of service provided by these banks due to their dissatisfaction with the physical aspects quality of the service as well as the quality of dealing (Mosbah, 2007). For developing this sector eliminating the failure and distortions, a strong administrative leadership with high management ability (Al-Hkimi, 2012), having sincere desire to change the followed traditional behavior shall be exist, because any action or change for the better is to discover and 
develop leaders known by the efficiency and performance (Mohamed \& Akeel, 2010), to place the modern technical means and the client as its marketing strategic axe, as well as to train the human resources in the modern marketing concepts in order to continuously commercialize the banking service.

Therefore, the researcher believes that there are some obstacles and problems that might hinder the marketing of banking services such as the types of prevailing leadership and its strength sources that depend thereon, as well as less awareness of the personnel training in terms of the dimensions and criteria for evaluating the service quality by the customer when the service provided and then the impact on customer satisfaction.

Through the foregoing clarification of the role of the administrative leadership in the Organization, as well as the role of human resources training and the impact on customer satisfaction, the study problem can be formulated in question:

Is there a positive relationship and impact of the administrative leadership on human resources training and customer satisfaction?

Branching from the main question following the previous sub-questions:

Is there a positive relation and impact of the administrative leadership on customer satisfaction?

Is there a positive relation and impact of the leadership on the training of human resources?

Is there a positive relation and the impact of human resources training on to customer satisfaction?

Does the human resources training play a mediator role in positive relation and impact of the administrative leadership on customer satisfaction?

\section{Research Objectives}

To verify the real relation between the administrative leadership and customer satisfaction.

To test the real role of the training as medial variable in the relation between the administrative leadership and customer satisfaction.

To determine the relation between the administrative leadership and human resources training.

To evaluate the relation between human resources training and customer satisfaction.

\section{Theoretical Framework}

\subsection{Relation between Administrative Leadership and Customer Satisfaction}

This paragraph will concern the administrative leadership as a potential factor through its power sources as first apparent factor (Structural, Experience, Personality, Bonus, Coercion) as a set of rules and dimensions that measure the power of the administrative leadership based on the classification (French \& Raven, 1959), which is was a pioneer in this field. The classification of leader force is came from (Legitimacy, Reference, Charisma, Bonus, Coercion, Experience). Furthermore, the morals in this field suggest that the most important power sources and the most frequent is the (Legitimate, Information, Reference, Experience) (Al-Jmili, 2004) force. Regarding the leadership styles, it will be reliance on the classification as per its behaviors and methods and manners for influencing its employees as a second apparent factor of administrative leadership. Among these styles (Democratic, Bureaucratic, Free), and the extent of carrying such styles and impact on the behavior of personnel and their motivation towards the provision of quality services achieved to customer satisfaction being as more leadership styles, which depended by managers in organizations (Abbas, 2012).

\subsection{Relation between Administrative Leadership and Human Resources Training}

This paragraph will concern the administrative leadership as a potential factor through its styles and power sources as a $\mathrm{n}$ apparent factors and its relation with the training of human resources as a potential factor and as a (dependent) variable through three apparent factors (Knowledges, Capacities, \& Rrends), especially which worked in the front desks and had direct contact with the customers, considering that any organization desired to achieve the required quality levels of service and ensured its continuity in the business world depends on processes to improve administrative systems and development of work as well as the development and training of its human resources.

\subsection{Relation between Human Resources Training and Customer Satisfaction}

This paragraph will concern the human resources training as a potential factor through three apparent factors (Knowledges, Capacities, \& Rrends), with the dimensions and criteria of service quality evaluation, which assesses the customer the level of service quality then affecting the degree of his satisfaction, in particular persons who worked front desks an having direct contact with customers, which may have an impact on the 
dependent variable as an independent variable for the dependent variable (customer satisfaction), considering that the achievement of the required service quality levels and ensure its continuity in the business world depends on the improvement and development operations, as well as human resources training.

\subsection{Relation between Administrative Leadership, Human Resources Training and Customer Satisfaction}

The researcher assumes there is an indirect relation and impact of administrative leadership on customer satisfaction through training of human resources, so it will be dealt with administrative leadership as potential factor through its power sources and styles as apparent factors as (Independent) variable, and its relation to the human resources training as a potential factor in three apparent factors (Knowledges, Capacities, \& Rrends), as a (Mediator) factor between the administrative leadership and customer satisfaction as a potential factor through several apparent factors representing in dimensions and criteria of service quality evaluation as (Dependent) factor or variable (see Figure 1).

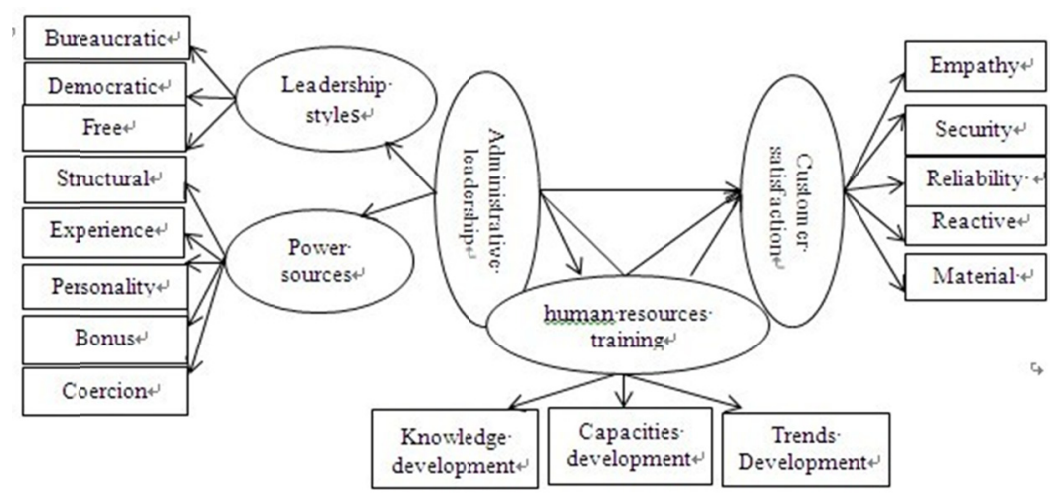

Figure 1. Conceptual framework

\section{Research Hypotheses}

Based on the conceptual framework proposed in the current study that guides our research objectives and questions, this study attempted to test the following research hypotheses:

There is a direct positive impact of the administrative leadership on customer satisfaction.

There is a direct positive impact of the administrative leadership on human resource training.

There is a direct positive impact of human resource training on customer satisfaction.

There is an indirect positive impact of the administrative leadership on customer satisfaction through the positive impact on the training of human resources.

\section{Method}

\subsection{Population \& Sample}

The population of this study consisted of managers and heads departments in commercial banks in Libya, which belong to the public sector with a percentage not less than $51 \%$ (Central Bank of Libya), including six prime public commercial banks and a number of 402 branches. This sample was selected due to the role such commercial banks play in supporting and developing the Libyan economy, their large size and long ages in conducting banking business as well as their geographical distributions in the study environment (Report of the Central Bank of Libya, 2012). Therefore, this study was scoped to the public banks only while excluding the other privately owned commercial banks from its investigation due to the small size of such private banks and their young ages in conducting banking business in the study environment (Abdurrahim, 2012). Because of the large size of the population, the sample size was determined by $5: 1$ of the overall study population (Hari, Black, 1998; Kline, 2005). Therefore, the size of the sample was $(92 \times 5=460)$. The researcher distributed (460) questionnaires to the study samples, and a number of (449) questionnaires were obtained whereas (11) questionnaires were lost and (7) of them were excluded because of the lack of the respondents' clear responses to the items of the questionnaire. Thus, the final overall number of the valid questionnaires subjected to the quantitative analysis in this study was (442) questionnaires. 


\subsection{Research Instruments}

In this regard, it is relied upon the questionnaire as a tool to gather the necessary information for this study as one of the most suitable scientific research tools that achieve the survey study objectives and to obtain information and facts associated with a determined reality, for achieving the study, a questionnaire is made for the purposes of processing the study questions and hypotheses.

\subsection{Confirmatory Factor Analysis}

The Structural Equation Modeling (AMOS) model-fitting program is used to test the validity constructs are to test the research hypotheses. The overall model fit is assessed by using four indices of the model goodness-of-fit: (1) the chi-square statistics; (2) the comparative fit index (CFI); (3) the minimum value of the discrepancy between the observed data and the hypothesized model divided by degrees of freedom (CMIN/DF) or normed chi-square. (4) In addition (RMSEA) of between (0.08) to (0.10) indicates a mediocre fit and would not employ a model a RMSEA greater than $0.1(>0.1)$.

\subsection{Construct Validity}

The employment of factor loading composite reliability (CR) and average variance extracted (AVE) were proposed by (Hair,Black,Babin, Anderson and Tatham ,2006) to determine the convergent validity if it equals to or greater than $0.5(\geq 0.5)$ and the composite reliability equals to or greater than $0.7(\geq 0.7)$ if were recommended by Hair et al.(2006). In addition (AVE) reading values should be greater than $0.5(\geq 0.5)$.

\subsection{Testing the Theoretically Hypothesized Research Model Using Integral Structural Equation Modeling:}

In this study used the structural equation modeling (SEM-AMOS) for testing the research hypotheses and objectives and test the relationship between the administrative leadership and training of human resources and customer satisfaction.

\section{Results}

\section{1 (CFA) of the Administrative Leadership Model}

\subsubsection{The Confirmatory Factor Analysis (CFA) of the Administrative Leadership}

The (CFA) of the Patterns of Administrative Leadership: The results of the goodness-of-fit of the final modified model of the patterns of administrative leadership as in Figure (2) showed that the normative Chi-Square (Chi-Square /degrees of freedom) was (3.626), and the relative strength index (CFI) was (.951). Moreover, the value of RMSEA was (.077).

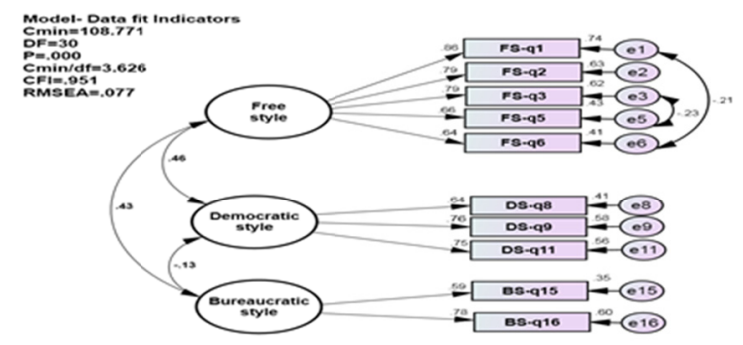

Figure 2. The final revised of the leadership Style model

\subsubsection{Construct Validity and Reliability}

In this study, we performed the factor lodgings for the items related to the model of the patterns of administrative leadership as shown in the modified model (Figure 2). The results show that the loadings for these items ranged from $(0.59$ to 0.86$)$, which were higher than $0.5(\geq 0.5)$. The values of the reliability of these items also ranged from (0.81 to 0.83 ), which was greater than 0.7 ( $\geq 0.7)$. Furthermore, the values of the divergent or discriminant validity of these three variables that constitute up the factor of the administrative leadership were $(0.57,0.52$, $0.47)$, being higher or greater than $0.5(\geq 0.5)$. Thus, these results indicate that the items of this factor of the patterns of administrative leadership are valid and reliable as shown in Table 1. 
Table 1. The items of factors of the patterns of administrative leadership

\begin{tabular}{|c|c|c|c|c|c|c|c|c|c|c|}
\hline No & $\begin{array}{l}\text { Latent } \\
\text { variables }\end{array}$ & Items & $\mathrm{R}$ & estimate & S. E & C. $\mathrm{R}$ & $\mathrm{P}$ & Loading & SMC & AVE \\
\hline $\begin{array}{l}\text { Fs } \\
\text { q1 }\end{array}$ & & $\begin{array}{l}\text { Administrative leadership not participate in } \\
\text { determining the duties. }\end{array}$ & .81 & 1.000 & - & - & - & .86 & .74 & .57 \\
\hline $\begin{array}{l}\text { Fs } \\
\mathrm{q} 2\end{array}$ & & $\begin{array}{l}\text { Administrative leadership not participate in } \\
\text { determining the work procedures except } \\
\text { required to do so. }\end{array}$ & .81 & .882 & .046 & 19.52 & .000 & .79 & .63 & - \\
\hline $\begin{array}{l}\text { Fs } \\
\text { q3 }\end{array}$ & & $\begin{array}{l}\text { Administrative leadership shall not criticized } \\
\text { the staff performance. }\end{array}$ & .81 & .832 & .045 & 18.55 & .000 & .79 & .62 & - \\
\hline $\begin{array}{l}\text { Fs } \\
\text { q5 }\end{array}$ & $\begin{array}{l}\text { Free } \\
\text { Style }\end{array}$ & $\begin{array}{l}\text { Administrative leadership participate in the } \\
\text { work execution. }\end{array}$ & .82 & .672 & .046 & 14.55 & .000 & .66 & .43 & - \\
\hline $\begin{array}{l}\text { Fs } \\
q 6\end{array}$ & & $\begin{array}{l}\text { The administrative leadership shall } \\
\text { participate to determine the work procedures } \\
\text { when required to do so. }\end{array}$ & .81 & .654 & .049 & 13.32 & .000 & .64 & .41 & - \\
\hline $\begin{array}{l}\text { Ds } \\
\text { q8 }\end{array}$ & & $\begin{array}{l}\text { Suggestions of employees to raise the quality } \\
\text { level shall be welcomed. }\end{array}$ & .82 & 1.000 & - & - & - & .64 & .41 & .52 \\
\hline $\begin{array}{l}\text { Ds } \\
\text { q9 }\end{array}$ & & $\begin{array}{l}\text { Administrative leadership knows how to } \\
\text { saturate the staff requirements. }\end{array}$ & .82 & 1.112 & .098 & 11.36 & .000 & .76 & .58 & - \\
\hline $\begin{array}{l}\text { Ds } \\
\text { q11 }\end{array}$ & $\begin{array}{l}\text { Democ } \\
\text { Style }\end{array}$ & $\begin{array}{l}\text { Executive procedures shall be determined in } \\
\text { participation with the administrative } \\
\text { leadership and staff. }\end{array}$ & .82 & 1.124 & .099 & 11.31 & .000 & .75 & .56 & - \\
\hline $\begin{array}{l}\text { Bs } \\
\mathrm{q} 15\end{array}$ & & $\begin{array}{l}\text { The staff do not participate in the planning for } \\
\text { achieving the objectives intended for the } \\
\text { bank. }\end{array}$ & .83 & 1.000 & - & - & - & .59 & .35 & .47 \\
\hline $\begin{array}{l}\text { Bs } \\
\text { q16 }\end{array}$ & $\begin{array}{l}\text { Bureaucratic } \\
\text { Style }\end{array}$ & $\begin{array}{l}\text { Administrative leadership welcomes no } \\
\text { suggestions from the staff for improving the } \\
\text { service quality. }\end{array}$ & .82 & 1.350 & .205 & 6.57 & .000 & .78 & .60 & - \\
\hline
\end{tabular}

S.E. Standard Error, C.R: Critical Ratio, P: Probability, SMC: Squared Multiple Correlation, AVE: Average Variance Extracted, R: Reliability.

\subsection{The Confirmatory Factor Analysis (CFA) of the Sources Leadership Power Model}

The (CFA) of the Sources leadership power: The results of the goodness-of-fit of the final modified model of the patterns of Sources leadership power as in Figure (3) showed that the normative Chi-Square (Chi-Square /degrees of freedom) was (2.294), and the relative strength index (CFI) was (.956). Moreover, the value of RMSEA was (.054).

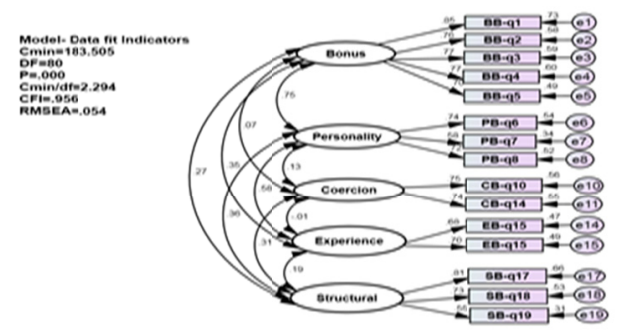

Figure 3. The final revised of the Sources leadership power model

\subsubsection{Construct Validity and Reliability}

In this study, we performed the factor lodgings for the items related to the model of the Sources leadership power as shown in the modified model (Figure 3 ). The results show that the loadings for these items ranged from $(.55$ to .85$)$, which were higher than $0.5(\geq 0.5)$. The values of the reliability of these items also ranged from $(.84$ to .85$)$, which was greater than $0.7(\geq 0.7)$. Furthermore, the values of the divergent or discriminant validity of these variables that constitute up the factor of the Sources leadership power were $(.59, .47, .56, .48, .50)$, being 
higher or greater than $0.5(\geq 0.5)$.Thus, these results indicate that the items of this factor of the Sources leadership power are valid and reliable as shown in Table 2.

\begin{tabular}{|c|c|c|c|c|c|c|c|c|c|c|}
\hline No & $\begin{array}{l}\text { Latent } \\
\text { variables }\end{array}$ & Items & $\mathrm{R}$ & estimate & S. E. & C. R. & $\mathrm{P}$ & Loading & SMC & AVE \\
\hline $\begin{array}{l}\text { BB } \\
\text { q1 }\end{array}$ & & $\begin{array}{l}\text { Bank administration gives periodically } \\
\text { bonuses to creative staff }\end{array}$ & .84 & 1.000 & - & - & & .85 & .73 & .59 \\
\hline $\begin{array}{l}\text { BB } \\
\text { q2 }\end{array}$ & Bonus & $\begin{array}{l}\text { Administrative leadership shall honor } \\
\text { the retired staff continuously and } \\
\text { permanently. }\end{array}$ & .84 & .867 & .048 & 18.22 & .000 & .76 & .58 & - \\
\hline $\begin{array}{l}\text { BB } \\
\text { q3 }\end{array}$ & & $\begin{array}{l}\text { Staff shall be awarded upon the } \\
\text { performance. }\end{array}$ & .84 & .840 & .045 & 18.52 & .000 & .77 & .59 & - \\
\hline $\begin{array}{l}\text { BB } \\
\text { q4 }\end{array}$ & & $\begin{array}{l}\text { Incentives and bonuses system } \\
\text { coordinates with the staff expectations. }\end{array}$ & .84 & .855 & .046 & 18.59 & .000 & .77 & .60 & - \\
\hline $\begin{array}{l}\text { BB } \\
\text { q5 }\end{array}$ & & $\begin{array}{l}\text { Promotion and awards linked to the } \\
\text { staff performance. }\end{array}$ & .84 & .681 & .042 & 16.29 & .000 & .70 & .49 & - \\
\hline $\begin{array}{l}\mathrm{PB} \\
\mathrm{q} 6\end{array}$ & & $\begin{array}{l}\text { Administrative leadership enjoys with } \\
\text { respect and gratitude towards their } \\
\text { personalities. }\end{array}$ & .85 & 1.000 & - & - & - & .72 & .52 & .47 \\
\hline PB-q7 & Personality & $\begin{array}{l}\text { Administrative leadership well listens } \\
\text { to who speaks. }\end{array}$ & .85 & .772 & .072 & 10.73 & .000 & .58 & .34 & - \\
\hline $\begin{array}{l}\mathrm{PB} \\
\mathrm{q} 8\end{array}$ & & $\begin{array}{l}\text { Administrative leadership enjoys with } \\
\text { leadership skills reinforcing the } \\
\text { credibility. }\end{array}$ & .85 & .864 & .067 & 12.94 & .000 & .74 & .54 & - \\
\hline $\begin{array}{l}\text { CB } \\
\text { q10 }\end{array}$ & Coercion & $\begin{array}{l}\text { Threat method shall be used when } \\
\text { faults committed. }\end{array}$ & .85 & 1.000 & - & - & - & .74 & .55 & .56 \\
\hline $\begin{array}{l}\mathrm{CB} \\
\mathrm{q} 11\end{array}$ & & $\begin{array}{l}\text { Performance and punishment shall be } \\
\text { linked by the management }\end{array}$ & .85 & .892 & .193 & 4.625 & .000 & .75 & .56 & - \\
\hline $\begin{array}{l}\text { EB } \\
\text { q14 }\end{array}$ & Expertise & $\begin{array}{l}\text { Administrative leadership shall depend } \\
\text { on the previous expertise for facing } \\
\text { such problem }\end{array}$ & .85 & 1.000 & - & - & - & .68 & .47 & .48 \\
\hline $\begin{array}{l}\text { EB } \\
q 15\end{array}$ & & $\begin{array}{l}\text { It shall be depended on the expertise } \\
\text { for promoting the staff as teamwork }\end{array}$ & .85 & .981 & .137 & 7.162 & .000 & .70 & .49 & - \\
\hline $\begin{array}{l}\text { SB } \\
\text { q17 }\end{array}$ & Structural & $\begin{array}{l}\text { Administrative leadership shall use the } \\
\text { official power for settlement of dispute } \\
\text { in bank }\end{array}$ & .85 & 1.000 & - & - & - & .81 & .66 & .50 \\
\hline $\begin{array}{l}\text { SB } \\
\text { q18 }\end{array}$ & & $\begin{array}{l}\text { Administrative leadership shall strictly } \\
\text { apply laws }\end{array}$ & .85 & .940 & .085 & 11.05 & .000 & .73 & .53 & - \\
\hline $\begin{array}{l}\text { SB } \\
\text { q19 }\end{array}$ & & $\begin{array}{l}\text { Supreme management shall approve } \\
\text { the offered power to control the work }\end{array}$ & .85 & .589 & .061 & 9.665 & .000 & .55 & .31 & - \\
\hline
\end{tabular}

S.E. Standard Error, C.R: Critical Ratio, P: Probability, SMC: Squared Multiple Correlation, AVE: Average Variance Extracted, R: Reliability.

\subsection{The Confirmatory Factor Analysis (CFA) of the Human Resources Training Model}

The (CFA) of the human resources training: The results of the goodness-of-fit of the final modified model of the patterns of human resources training as in Figure 4 show that the normative Chi-Square (Chi-Square /degrees of freedom) was (2.263), and the relative strength index (CFI) was (.978). Moreover, the value of RMSEA was (.054).

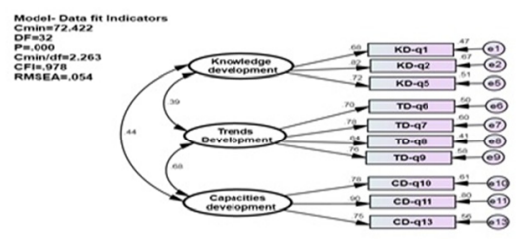

Figure 4. The final revised of the human resources training model 


\subsubsection{Construct Validity and Reliability}

In this study, we performed the factor lodgings for the items related to the model of the human resources training as shown in the modified model (Figure 4). The results show that the loadings for these items ranged from (.64 to .90$)$, which were higher than $0.5(\geq 0.5)$. The values of the reliability of these items also ranged from (.89 to .89), which was greater than 0.7 ( $\geq 0.7)$. Furthermore, the values of the divergent or discriminant validity of these three variables that constitute up the factor of the human resources training were $(.55, .52, .66$,), being higher or greater than $0.5(\geq 0.5)$. Thus, these results indicate that the items of this factor of the human resources training are valid and reliable as shown in Table 3 .

\begin{tabular}{|c|c|c|c|c|c|c|c|c|c|c|}
\hline No & $\begin{array}{l}\text { Latent } \\
\text { variables }\end{array}$ & Items & $\mathrm{R}$ & estimate & S. E & C. $\mathrm{R}$ & $\mathrm{P}$ & Loading & SMC & AVE \\
\hline $\begin{array}{l}\mathrm{KD} \\
\mathrm{q} 1\end{array}$ & Knowledge & $\begin{array}{l}\text { Data shall be updated regarding the } \\
\text { organization's plans and objectives. }\end{array}$ & .89 & 1.000 & - & - & - & .68 & .47 & .55 \\
\hline $\mathrm{KD}$ & & $\begin{array}{l}\text { Technical knowledge shall be renewed by } \\
\text { service production ways and materials. }\end{array}$ & .89 & 1.194 & .096 & 12.43 & .000 & .82 & .67 & - \\
\hline $\begin{array}{l}\mathrm{KD} \\
\mathrm{q} 5\end{array}$ & & $\begin{array}{l}\text { Knowledge shall be developed in various } \\
\text { administrative jobs in the organization }\end{array}$ & .89 & 1.085 & .089 & 12.12 & .000 & .72 & .51 & - \\
\hline $\begin{array}{l}\text { TD } \\
\mathrm{q} 6\end{array}$ & & $\begin{array}{l}\text { Emotion shall be developed at employees in } \\
\text { terms of liability in the organization. }\end{array}$ & .89 & 1.000 & - & - & - & .70 & .50 & .52 \\
\hline $\begin{array}{l}\mathrm{TD} \\
\mathrm{q} 7\end{array}$ & Trends & $\begin{array}{l}\text { Emotion shall be developed in terms of team } \\
\text { spirit between the employees and } \\
\text { management in the organization }\end{array}$ & .89 & 1.081 & .077 & 13.92 & .000 & .78 & .60 & - \\
\hline $\begin{array}{l}\mathrm{TD} \\
\mathrm{q} 8\end{array}$ & & $\begin{array}{l}\text { Emotion shall be developed by the } \\
\text { importance of distinction for the required } \\
\text { service produced. }\end{array}$ & .89 & 0.882 & .074 & 11.79 & .000 & .64 & .41 & - \\
\hline $\begin{array}{l}\text { TD } \\
\text { q9 }\end{array}$ & & $\begin{array}{l}\text { Cooperation spirit shall be developed } \\
\text { between the employees and administrative } \\
\text { leadership in the organization. }\end{array}$ & .89 & 1.072 & .078 & 13.72 & .000 & .76 & .58 & - \\
\hline $\begin{array}{l}\mathrm{CD} \\
\mathrm{q} 10\end{array}$ & & $\begin{array}{l}\text { Skills and capacities shall be developed to } \\
\text { take the appropriate decision. }\end{array}$ & .89 & 1.000 & - & - & - & .78 & .61 & .66 \\
\hline $\begin{array}{l}\mathrm{CD} \\
\mathrm{q} 11\end{array}$ & Capacities & $\begin{array}{l}\text { Employees' skills shall be developed for } \\
\text { solving problems faced during the work. }\end{array}$ & .89 & 1.262 & .068 & 18.38 & .000 & .90 & .80 & - \\
\hline $\begin{array}{l}\mathrm{CD} \\
\mathrm{q} 13\end{array}$ & & $\begin{array}{l}\text { Employees' skills shall be developed in } \\
\text { terms o expression and discussion during } \\
\text { providing the service to the customer. }\end{array}$ & .89 & 0.945 & .059 & 15.94 & .000 & .75 & .56 & - \\
\hline
\end{tabular}

S.E. Standard Error, C.R: Critical Ratio, P: Probability, SMC: Squared Multiple Correlation, AVE: Average Variance Extracted, R: Reliability.

\subsection{The Confirmatory Factor Analysis (CFA) of the Customer Satisfaction Model}

The (CFA) of the human resources training: The results of the goodness-of-fit of the final modified model of the patterns of Customer satisfaction model as in Figure (5) showed that the normative Chi-Square (Chi-Square /degrees of freedom) was (3.353), and the relative strength index (CFI) was (.939). Moreover, the value of RMSEA was (.073).

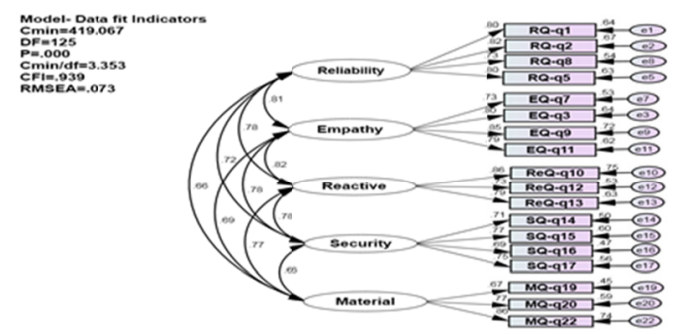

Figure 5. The final revised of the customer satisfaction model 


\subsubsection{Construct Validity and Reliability}

In this study, we performed the factor lodgings for the items related to the model of the Customer satisfaction as shown in the modified model (Figure 5). The results show that the loadings for these items ranged from (.67 to .86$)$, which were higher than $0.5(\geq 0.5)$. The values of the reliability of these items also ranged from (.94 to .94), which was greater than $0.7(\geq 0.7)$. Furthermore, the values of the divergent or discriminant validity of these variables that constitute up the factor of the human resources training were $(.62, .63, .64, .53, .60)$, being higher or greater than $0.5(\geq 0.5)$.Thus, these results indicate that the items of this factor of the Customer satisfaction are valid and reliable as shown in Table 4.

\begin{tabular}{|c|c|c|c|c|c|c|c|c|c|c|}
\hline No & $\begin{array}{l}\text { Latent } \\
\text { variables }\end{array}$ & Items & $\mathrm{R}$ & estimate & S. E & C. $\mathrm{R}$ & $\mathrm{P}$ & Loading & SMC & AVE \\
\hline $\begin{array}{l}\text { RQ } \\
\text { q1 }\end{array}$ & & $\begin{array}{l}\text { Suggestions proposed by customers shall } \\
\text { be took in consideration. }\end{array}$ & .94 & 1.000 & - & - & - & .80 & .64 & .62 \\
\hline $\begin{array}{l}\text { RQ } \\
\text { q2 }\end{array}$ & Reliability & $\begin{array}{l}\text { Service shall be obtained in appropriate } \\
\text { time }\end{array}$ & .94 & .989 & .053 & 18.68 & .000 & .82 & .67 & - \\
\hline $\begin{array}{l}\text { RQ } \\
\text { q8 }\end{array}$ & & $\begin{array}{l}\text { Problems faced the customers during the } \\
\text { service shall be took in consideration. }\end{array}$ & .94 & .966 & .053 & 18.68 & .000 & .80 & .63 & - \\
\hline $\begin{array}{l}\text { RQ } \\
\text { q5 }\end{array}$ & & $\begin{array}{l}\text { Required service shall be completed when } \\
\text { no customers. }\end{array}$ & .94 & .834 & .051 & 16.29 & .000 & .73 & .54 & - \\
\hline $\begin{array}{l}\text { EQ } \\
\text { q7 }\end{array}$ & & $\begin{array}{l}\text { Customer's requirements shall be } \\
\text { continuously studied. }\end{array}$ & .94 & 1.000 & - & - & - & .73 & .53 & .63 \\
\hline $\begin{array}{l}\text { EQ } \\
\text { q3 }\end{array}$ & Empathy & Customers shall participate in social sides. & .94 & 1.171 & .071 & 16.32 & .000 & .80 & .64 & - \\
\hline $\begin{array}{l}\text { EQ } \\
\text { q9 }\end{array}$ & & $\begin{array}{l}\text { Short waiting periods for customers shall } \\
\text { be maintained. }\end{array}$ & .94 & 1.287 & .074 & 17.25 & .000 & .85 & .72 & - \\
\hline $\begin{array}{l}\text { EQ } \\
\text { q11 }\end{array}$ & & $\begin{array}{l}\text { Customer's requirement shall be } \\
\text { acquainted since first time. }\end{array}$ & .94 & 1.131 & .070 & 16.05 & .000 & .79 & .62 & - \\
\hline $\begin{array}{l}\text { ReQ } \\
\text { q10 }\end{array}$ & & $\begin{array}{l}\text { Quick answer for customer inquiry with } \\
\text { smile. }\end{array}$ & .94 & 1.000 & - & - & - & .86 & .75 & .64 \\
\hline $\begin{array}{l}\text { ReQ } \\
\text { q12 }\end{array}$ & Reactive & $\begin{array}{l}\text { Employees shall deal with customers with } \\
\text { high morals and ethics }\end{array}$ & .94 & .704 & .040 & 17.25 & .000 & .73 & .53 & - \\
\hline $\begin{array}{l}\text { ReQ } \\
\text { q13 }\end{array}$ & & No distinction between customers & .94 & .927 & .047 & 19.60 & .000 & .79 & .63 & - \\
\hline $\begin{array}{l}\text { SQ } \\
\text { q14 }\end{array}$ & & $\begin{array}{l}\text { Data and information Privacy regarding } \\
\text { the customers shall be respected. }\end{array}$ & .94 & 1.000 & - & - & - & .71 & .50 & .53 \\
\hline $\begin{array}{l}\text { SQ } \\
\text { q15 }\end{array}$ & Security & $\begin{array}{l}\text { Mistake percentage shall be reduced when } \\
\text { required serviced provided. }\end{array}$ & .94 & 1.090 & .075 & 14.52 & .000 & .77 & .60 & - \\
\hline $\begin{array}{l}\text { SQ } \\
\text { q16 }\end{array}$ & & $\begin{array}{l}\text { Confidence shall be maintained when } \\
\text { service provided as required by the } \\
\text { customers }\end{array}$ & .94 & .940 & .071 & 13.07 & .000 & .69 & .47 & - \\
\hline $\begin{array}{l}\text { SQ } \\
\text { q17 }\end{array}$ & & $\begin{array}{l}\text { Behaviors for acquiring confidence to } \\
\text { customer in the bank shall be followed. }\end{array}$ & .94 & 1.097 & .078 & 14.07 & .000 & .75 & .56 & - \\
\hline MQ & & Recent equipment shall be provided for & .94 & 1.000 & - & & - & .67 & .45 & .60 \\
\hline
\end{tabular}




\begin{tabular}{|c|c|c|c|c|c|c|c|c|c|c|}
\hline q19 & & required service produced. & & & & & & & & \\
\hline $\begin{array}{l}\text { MQ } \\
\text { q20 }\end{array}$ & Material & $\begin{array}{l}\text { Parking for customers' cars, to be followed } \\
\text { to the bank. }\end{array}$ & .94 & 1.529 & .112 & 13.64 & .000 & .77 & .59 & - \\
\hline $\begin{array}{l}\text { MQ } \\
\text { q22 }\end{array}$ & & $\begin{array}{l}\text { Comfortable waiting halls shall be } \\
\text { provided for customers. }\end{array}$ & .94 & 1.647 & .113 & 14.53 & .000 & .86 & .74 & - \\
\hline
\end{tabular}

S.E. Standard Error, C.R: Critical Ratio, P: Probability, SMC: Squared Multiple Correlation, AVE: Average Variance Extracted, R: Reliability.

\section{Testing the Theoretical Model Using the Integrated Formula of Structural Equation Modeling}

\subsection{Testing the Standard Theoretical Research Model Using a CFA}

\subsubsection{Main Standard Model}

After confirming the statistical assumptions required by the analysis using the SEM, we tested the goodness of fit between the model and collected data. This was followed by testing the proposed research hypotheses in the conceptual model. Figure 6 shows a diagramic representation of the proposed conceptual model of the study using the SEM via the AMOS program. This includes the administrative leadership as the independent factor that consists of two potential dimensions: patterns or styles of leadership represented by three sub-factors known as democratic, bureaucratic and free, and the power source represented by five sub-factors known as structural, experience, personality, bonus and coercion force. In addition to human resources as a dimension, it was used in the present study as a mediator factor which consists of three sub-factors: knowledge, capacities and trends. Regarding the customer satisfaction as a dependent factor, it consists of five sub-factors namely; materialistic, reactive, security, reliability and empathy. It was found that the proposed model of the study fits the data collected from the context of the study. Furthermore, the same figure shows the indices of the goodness of fit between the model and the data collected in the present study the Figure 6.

Moreover, Figure 6 shows that the correlation values are higher than $(.85)$ and the value of correlation between the factor of the administrative leadership and the factor of human resource training is (1.01), which is higher than (1). Such results indicated that there is a problem concerning the linear or the strong internal correlation (Multicollinearity), thus leading to another problem known as non-reasonable estimation (Offending Estimation) in the SEM. It is also shown that the RSI value was equal to (.89), which is less than (.90). These results are indicative of the need for modifying the model of the present study required some (model modification). In addition, the RMSEA index or the relative approximate error index is equal to (.09), which is greater than the (T value). Furthermore, the factor loadings of the bureaucratic leadership pattern, the structural power and the coercion force were all low $(.07, .33,-.19)$, respectively.

Through All the above values and indices indicate that there was a need to modify and improve the model in the current study. Therefore, based on this, we removed those variables with low loadings as compared to other remaining variables seen in Figure 6.

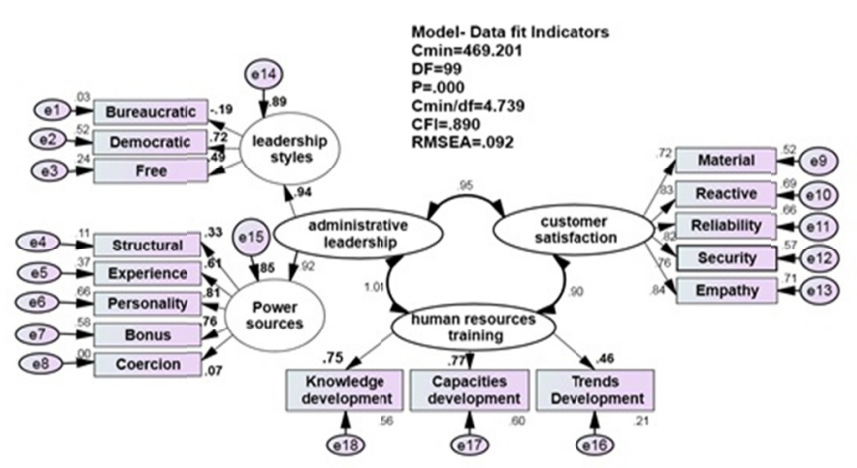

Figure 6. Main measurement model

\subsubsection{Modified Measurement Model}

After modifying the model of the study by removing the three variables which achieved low loadings, the 
modified model was free of errors related to the high correlation values (e.g., higher than .85) as pointed out by Brown (2006). This also indicates that the modified model is free from the above stated problem concerning the strong inner correlations (Multicollinearity) as shown in Figure 7 and also that the modified model is free from the previously stated problem related to the offending estimation.

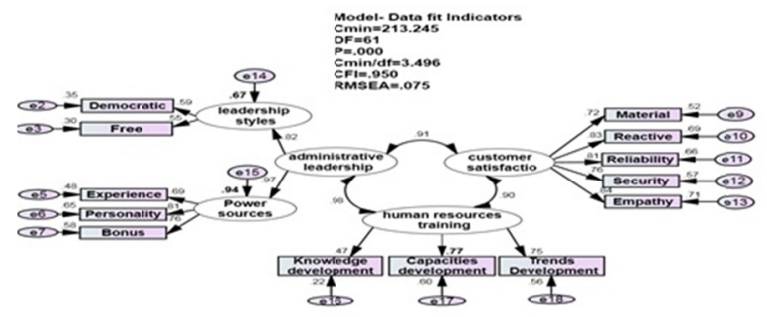

Figure 7. Modified measurement model

\subsection{Testing the Research Model Fit with Sample Data}

Based on the values and model fit indices between the research model and the sample data as shown in Table (5) and Figure 7, it is evident that there is a goodness of fit between proposed model (administrative leadership, human resources training, customer satisfaction) and the data collected. Based on the value of the Chi-square (213.245), degrees of freedom (61) and the significance level (.000) as a statistic equation and because of the significance level affected by the sample size whenever it was more than 200 (Hair \& Black, 2010), we tested the quality of goodness of fit through other indices such as the normative Chi-Square which was (3.496) and less than (5). As shown, the RSI value equal to (.950), which was greater than (.90), thus indicating and confirming that there are correlations among the variables proposed in the research model, and that such values are far from the value of zero that underlies the lack of correlations among the variables in the model. Moreover, the value of the RMSEA index or the relative approximate error index was (.075) and this confirmed that the proposed research model is widespread over the overall population.

Table 5 .

\begin{tabular}{|c|c|c|c|c|}
\hline \multirow[t]{2}{*}{ Indicators consistency } & \multicolumn{2}{|l|}{ Standard Model } & \multirow{2}{*}{$\begin{array}{l}\text { Structural model } \\
\text { figure: } 4 \\
\text { index value }\end{array}$} & \multirow{2}{*}{$\begin{array}{l}\text { Function value on the quality } \\
\text { of conformity }\end{array}$} \\
\hline & $\begin{array}{l}\text { Main, figure: } 2 \\
\text { index value }\end{array}$ & $\begin{array}{l}\text { Amended, figure : } 3 \\
\text { index value }\end{array}$ & & \\
\hline Cmin & 469.201 & 213.245 & 228.466 & --- \\
\hline $\mathrm{df}$ & 99 & 61 & 61 & --- \\
\hline $\mathrm{P}$ & .000 & .000 & .000 & Non \\
\hline $\mathrm{Cmin} / \mathrm{Df}$ & 4.739 & 3.496 & 3.745 & Less than (5) \\
\hline CFI & .890 & .950 & .945 & More (.90) \\
\hline RMSEA & .092 & .075 & .079 & Less than $(.08)$ \\
\hline
\end{tabular}

As From these values and indices of goodness of fit between the proposed model that consists of the three specified factors and the collected data, it can be concluded that it is possible to test the factor loadings and the internal relationships between the factors and their variables as hypothesized in the research model.

\subsection{Testing the Efficiency of Factors Saturations in the Model}

There are correlations or relations between each main factor and its variables that represent it (e.g., the relations between the potential factor of administrative leadership and its sub-factors or the patterns: democratic and free), and the same can be said about the other remaining potential factors and the variables that represent them. Accordingly, the value of such relation should be at least (.50). As shown from the analysis in Figure 7, the weights between the potential factor of administrative leadership and its patterns as well as sources of power were higher as they obtained $(.82, .97)$, respectively in addition to the large size of the impact between them as $(.67, .94)$, respectively.

It As shown from the model illustrated in Figure 7 and Table 6, we find that the loadings or correlations of the 
variables represented by the rectangular shapes and their potential factors exemplified by the oval circuits were high and exceeded (.50). These are usually called saturations, loadings or estimates, which, in this study, ranged from the highest correlation (.84) between customer satisfaction and the variable of the quality of empathy to the lowest one (.55) between the administrative leadership and the variable of the free pattern. In addition, Table 6 presents the $T$ value of each relation between the potential factors and variables that represent them. It can be seen that the $\mathrm{T}$ value was higher than (1.964) for all such identified relations, thus being statistically significant at (.05). Such results confirm the existing remarkable relations or correlations between the potential factors and their variables.

Table 6 .

\begin{tabular}{llllllll}
\hline Observed variables & Latent variables & Estimate & S. E & C. R & P & Loading & S. M. C \\
\hline Leadership & Democratic & 1.000 & - & - & - & .60 & .35 \\
styles & Free & 2.070 & .222 & 9.325 & 0.000 & .55 & .30 \\
Power & Experience & 1.000 & - & - & - & .69 & .47 \\
sources & Personality & 1.700 & .103 & 16.577 & 0.000 & .81 & .65 \\
& Bonus & 3.117 & .200 & 15.592 & 0.000 & .76 & .58 \\
human resources training & Knowledge & 1.000 & - & - & - & .47 & .22 \\
& Capacities & 2.092 & .220 & 9.510 & 0.000 & .77 & .60 \\
& trends & 2.204 & .234 & 9.412 & 0.000 & .75 & .56 \\
Customer & Material & 1.000 & - & - & - & .72 & .52 \\
satisfaction & Reactive & 1.130 & .067 & 16.922 & 0.000 & .83 & .69 \\
& Security & 1.429 & .086 & 16.592 & 0.000 & .81 & .66 \\
& Credibility & 1.081 & .070 & 15.441 & 0.000 & .76 & .57 \\
\hline
\end{tabular}

S.E. Standard Error, C.R.: Critical Ratio, P: Probability, SMC: Squared Multiple Correlation.

\subsection{Testing the Correlations among the Main Factors in the Research Model}

As shown from Figure 7 and Table 7, it is evident that all the correlations among the three main factors: administrative leadership, human resource training and customer satisfaction were statistically significant as their statistical $\mathrm{T}$ values were higher than (1.964) and the significance level (probability value) was less than (.05). The values of such correlations among the three factors ranged between (.90) and (.98). Based on the divisions of the proposed research model (administrative leadership, human resource training and customer satisfaction), this required investigating the research hypotheses or the structural research model.

Table 7.

\begin{tabular}{|c|c|c|c|c|c|c|c|}
\hline Latent variables & Correlations & Latent variable & Estimate & S. E & C. $\mathrm{R}$ & $\mathrm{P}$ & $\mathrm{C}$ \\
\hline administrative leadership & $\mid<------>$ & customer satisfaction & 2.368 & .234 & 10.120 & $* * *$ & .909 \\
\hline human resources training & $<------>$ & customer satisfaction & 2.133 & .277 & 7.696 & $* * *$ & .899 \\
\hline human resources training & $<------>$ & administrative leadership & 1.300 & .166 & 7.842 & $* * *$ & .977 \\
\hline
\end{tabular}

S.E. Standard Error, C.R.: Critical Ratio, P: Probability, C: Correlation.

\subsection{Testing the Structural Modeling of the Research Model: Structural Model}

The structural model as shown in Figure 6 differs from the measurement model as shown in Figure 7. In the structural model, the independent and dependent variable as well as medial variable are determined by the unidirectional arrow $(\rightarrow)$, so the model is completely identical to the proposed study. Regarding the measurement model, the relations among the three factors represent independent relations which are reflected or expressed by the bidirectional arrow $(\leftrightarrow)$, but without determining the independent variable, the dependent 
variable and the mediating variable. Furthermore, we find that the model fits the sample data through the structural model which is not totally different from the measurement model. Based on the model fit indices in Table 5 and Figure 7. There is a goodness of fit between the research model and the sample collected data. Based on the value of the Chi-square (228.466), degrees of freedom (61) and the significance level (.000) as a statistic equation and because of the significance level affected by the sample size whenever it was more than 200 (Hair \& Black, 2010), we again used other indices such as the normative Chi-Square to test the quality of goodness of fit. The normative Chi-Square was (3.745), which is less than (5). As shown, the RSI value equal to (.945), which was higher than (.90). This result indicates and confirms the existing correlations among the variables proposed in the research model, and these values are far from the value of zero that underlies the lack of correlations among the variables in the model. In addition, the value of the RMSEA index or the relative approximate error index was (.079), thus confirming the widspeadness of the proposed model over the overall population.

Based on the above values and indices of goodness of fit between the research model that comprises three determined factors and the collected data, the proposed research hypotheses were tested as follows :

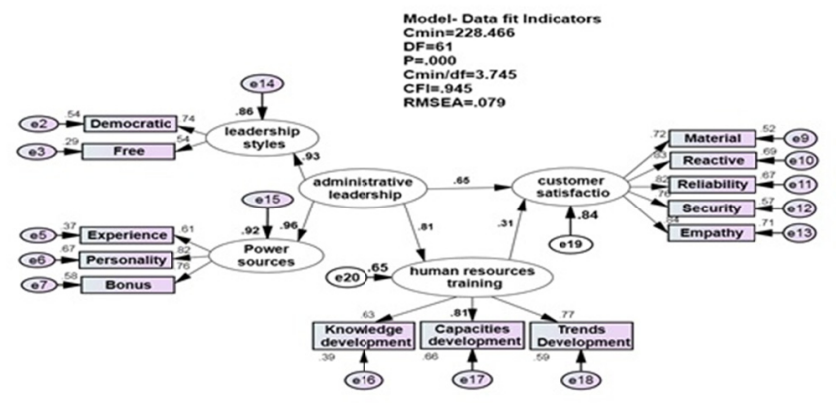

Figure 8. Structural model

\section{Testing the Main Research Hypotheses}

After confirming the efficiency of the factor loadings and correlations among the variables and their factors as previously discussed, we tested the following research hypotheses that determine the relations or correlations among the three main factors of the study:

\subsection{The Impact of Administrative Leadership on Customer Satisfaction}

The first hypothesis confirms that there is a positive and direct impact of the administrative leadership on customer satisfaction. As shown in Figure (8) that illustrates the conceptual model of the study as well as Table 8 that shows the outputs of the Amos program, the first research hypothesis was statistically significant since the $\mathrm{T}$ value (6.794) was higher than (1.964), and the value of the significance level (.000) was also statistically significant since it was less than (.05). In addition, the value of the path coefficient or estimates was equal to (.65) and shows a positive direction which emphasizes that the increased attention to administrative leadership leads to higher customer satisfaction.

Table 8

\begin{tabular}{llllllll}
\hline Latent Construct & & Latent Construct & Estimate & S. E & C. R & P-Value & S. R. W \\
\hline administrative leadership & $--->$ & customer satisfaction & .743 & .109 & 6.794 & .000 & .65 \\
administrative leadership & $--->$ & human resources training & .725 & .070 & 10.340 & .000 & .81 \\
human resources training & $--->$ & customer satisfaction & .400 & .112 & 3.573 & .000 & .31 \\
\hline
\end{tabular}

S.E. Standard Error, C.R.: Critical Ratio, S.R.W: Standardized Regression Weights.

\subsection{Administrative Leadership \& Human Resource Training}

The second hypothesis indicates that there is a direct impact of the administrative leadership on human resources training, and given to the default theoretical model Figure 8 and outputs Amos program Table 8, the hypothesis was a statistical significant given that the statistical value of (T) (10.340) was higher than the stake (1.964), and 
the value of the significance level (.000) is significant statistically less than stake (.05), in addition to the value of the path coefficient or standard estimates equal to (.81) and has a positive direction which emphasizes the increased attention to administrative leadership leads to higher human resource training, the effect size was (.65), that means $(65 \%)$ of human resources training due to the administrative leadership. This is significant impact the potential variables where it is greater than $(25 \%)$.

\subsection{Human Resource Training \& Customer Satisfaction}

The third hypothesis indicates that there is a positive and direct impact of human resources training on improving customer satisfaction, as in the previous steps to the default theoretical model and outputs of Amos program scheme Table 6, the hypothesis was a statistical significant given that the statistical value of (T) (3.573) was higher than the stake (1.964), and the value of the significance level (.000) is significant statistically less than stake (.05), in addition to the value of the path coefficient or standard estimates equal to (.31) and has a positive direction which emphasizes the increased attention to human resource training leads to higher customer satisfaction, in addition the total effect size on customer satisfaction (.84), this means that (84\%) of customer satisfaction due to both the administrative leadership and human resources training. This size is considered due to significant impact on the potential variables. The analysis also indicated in terms of importance of the effect that the effect sixe of administrative leadership was (.65), most important of human resources training, which its effect size was (.31) and the most influential on the high level of customer satisfaction.

\subsection{The Impact of Administrative Leadership on Customer Satisfaction through Human Resource Training}

The fourth research hypothesis confirms that there is an indirect impact of the administrative leadership on customer satisfaction through the mediating factor of human resource training. As seen in Table 9 and Figure 8 , the value of the indirect impact or relation is (.25), which was obtained by multiplying the value of the path coefficient or estimates of the relation between administrative leadership and human resource training (.81) by the value of the path coefficient or estimates of the relation between human resource training and customer satisfaction (.31). The overall impact estimated was (.90) which was resulting from the addition of the overall path coefficient or direct impact of the administrative leadership on customer satisfaction (.65) to the overall path coefficient or non-direct impact of the administrative leadership on customer satisfaction $(.65+.25)$.

Table 9. The value of the indirect impact

\begin{tabular}{lllll}
\hline Independent & Mediator & Dependent & Indirect Effect & Total Effect \\
\hline administrative leadership & human resources training & customer satisfaction & .25 & .90 \\
\hline
\end{tabular}

\section{Conclusion}

The results of statistical analysis using the SEM-AMOS for the proposed research hypotheses indicate that all the factors of the study have positive relations and significant impact on customer satisfaction. Such results corroborate those results obtained in previous studies (Abu Zeid, 2012; Pangil, 2011; Issa, 2014; Al-Otaibi, 2014; Lori, 2011). These results are considered as the main findings through which the researcher achieved the research objectives in this study. The results of the present study imply that in reality, achieving customer satisfaction depends on the patterns of the administrative leadership as well as the power sources for the administrative leadership in the bank. The interesting part of these results is that the results proved that the patterns of the democratic and free leadership had a positive impact on customer satisfaction as opposed to the bureaucratic pattern of leadership that showed a negative impact on customer satisfaction. As far as the power sources of the administrative leadership are concerned, customer satisfaction depends on the experience and the strong personality as well as the bonus as opposed to the structural power that had a negative impact on customer satisfaction. The current study obtained another result showing that human resource training plays an important role as a mediator between (1) the administrative leadership through the democratic and free patterns of leadership as well as the strong personality, experience and reward, and (2) customer satisfaction by developing their knowledge and abilities as well as their attitudes towards the dimensions and criteria used for evaluating the quality of services offered to customers while accessing or obtaining the service.

\section{References}

Abbas, A. (2012). Influence of Administrative Leadership styles on making-decision process. Journal of Islamic Studies for Economical \& Administrative Studies, 20(1).

Abdurrahim, A. M. (2012). Some factors determining the creativity and influence on creative administrator 
behavior at managers in the Libyan commercial banking sector. AL-MOKHTAR Journal for Economical Sciences-OmarAl-Mokhtar University.

Abu Zeid, K. T. (2010). The impact of organizational strength on job creation for those working in the commercial banks in Jordan. Middle East University. Business Management.

Aiyad, A. M. (2013). Role of Administrative Leadership University of Sciences \& Technologies in application of the comprehensive quality management. Arab Journal for securing the university education (11th ed.).

Al-Hkimi, I. A. (2012). Role of Active Leadership style in application of the comprehensive quality management in some higher education institutions of Yemen. Sana's, Faculty of Banking Financial Sciences.

Al-Jmili, K. T. A. (2004). Influence of culture and organizational power in leadership behavior. Practical study in public banking sector. Baghdad-Mustansariya University- Faculty of Management \& Economics.

Al-Khudr, O. (2005). Organizational Psychology. Kuwait-AL-FALAH Library for Publication \& Distribution. First Edition.

Al-Otaibi, S. A. (2014). Styles of administrative leadership and its relationship with the management of organizational change from the perspective of workers in the affairs of the patients in the Prince Sultan Military Medical Riyadh.

Ben Gadara, F. O. (2013). Researches \& Studies on Central Bank of Libya. Retrieved from $\mathrm{http} / / / \mathrm{cbl} . \mathrm{gov} .1 \mathrm{y} / \mathrm{pdf} / 09 \mathrm{X} 3 \mathrm{~V} 96 \mathrm{mnc} 4 \mathrm{gaQ} 3 \mathrm{kSDK} . \mathrm{pdf}$

Ben Ishi, A. (2012). Trends of modern training and evaluation of personnel performance (1st ed.). Jordan: Osama Distribution \& Publishing house.

Brown, D., \& Harrey, D. (2006). An experienyaial approach to organizational development (7th ed.). Prentice-Hall: New Jersey.

Doreen, H. M. (2013). Advanced statistical analysis of data (1st ed.). Amman: AL-MASIRA Publishing House.

Essa, H. A. (2014). Organizational climate totter on the job performance of employees. A field study on the management of ports sexual affairs. Passports and Residence at the Ministry of Interior. Bahrain: University of Applied Sciences. Faculty of Administrative Sciences.

Hair, J. F., Anderson, R. E., Tatham, R. L., \& Black, W. (2010). Multivariate Date Analysis (5th ed.). Prentice-Hall: New Jersey.

Hraim, H. (2003). Behavior of Individuals \& Groups in business organizations. AL-HAMED Distribution \& Publishing House.

Kline, R. B. (2011). Principles and practice of structural equation modelling (2nd ed.). New York: Guilford Press.

Lori, B. (2011). The Impact of Training on Employee Advancement. Doctoral Dissertation, University of North Texas, ProQuest Library.

Miller, M. (1995). Coefficient alpha: A basic introduction from the perspectives of classical test theory and Structural Equation Modeling.

Mohamed, Y. K., \& Akeel, A. G. (2010). Administrative Leadership and Change in Organization. International Conference on Islamic Call \& Management: Practices \& Horisons. Universiti Science Islamic Malaysia Faculty of Leadership \& Management.

Mosbah, A. R. (2007). Quality of material sides and deal for merchandizing banking services and influence on customer satisfaction. Libya/ Academy of Postgraduate Studies-Tripoli.

Pangil, F. (2011). The Relationship between Organizational Climate and Job Satisfaction: The Case of a Government Agency in Malaysia. International Journal of Humanities and Social Science.

Third annual report of department of bank and money control for financial years 2010-2011. Retrieved from http://www.cbl.gov.ly

\section{Copyrights}

Copyright for this article is retained by the author(s), with first publication rights granted to the journal.

This is an open-access article distributed under the terms and conditions of the Creative Commons Attribution license (http://creativecommons.org/licenses/by/3.0/). 